\title{
Pengembangan Media Pembelajaran Interaktif Berbasis Flash Pada Materi Klasifikasi Hewan Vertebrata Mata Pelajaran Biologi Kelas VII SMP
}

\author{
Titin Fitri Ningsih ${ }^{1 *}$, Hariman Bahtiar2, Yupi Kuspandi Putra ${ }^{3}$ \\ ${ }^{1}$ Program Studi Teknik Informatika, Universitas Hamzanwadi \\ 2,3Program Studi Sistem Informasi, Universitas Hamzanwadi \\ *titinfitriy08@gmail.com
}

\begin{abstract}
Abstrak
Perkembangan teknologi telah memasuki segala bidang kehidupan salah satunya di bidang pendidikan. Serta pentingnya media pembelajaran bagi guru dan siswa dalam melakukan proses belajar mengajar agar lebih menarik, efektif dan efisien terutama pada masa pandemi covid 19 sepeti saat ini. Sehingga guru harus mengatur kegiatan belajar mengajar tetap berjalan meskipun melalui sistem daring, serta memastikan kegiatan belajar agar lebih menarik minat siswa, mengurangi kejenuhan siswa dalam belajar, serta memudahkan siswa memahami materi dengan cepat. Untuk itu diperlukan media pembelajaran interaktif agar mempermudah guru dan siswa melakukan proses belajar mengajar terutama pada masa pandemi, selain itu juga guru merasa terbantu dalam menyampaikan materi terhadap siswa melalui media pembelajaran interaktif. Dengan menggunakan software Adobe Flash. Perangkat lunak computer yang digunakan untuk membuat animasi gambar bergerak 2 dimensi (2D). Hal itu akan diterapkan pada pembelajaran tentang klasifikasi hewan vertebrata. Diharapkan membantu guru dalam mata pelajarann biologi untuk memvisualiasikan klasifikasi hewan vertebrata dalam obejek 2D. Guru dalam menjalankan perannya pada peroses pembelajaran, membutuhkan alat bantu yang dapat menyampaikan informasi kepada siswa. Sehingga dapat di manfaatkan sebagai sarana untuk penyampaikan materi pembelajaran.
\end{abstract}

Kata kunci: Adobe flash, animasi, covid19, klasifikasi hewan, media pembelajaran.

\begin{abstract}
The development of technology has entered all areas of life, one of which is in the field of education. As well as the importance of learning media for teachers and students in carrying out the teaching and learning process to make it more interesting, effective and efficient, especially during the COVID-19 pandemic as it is today. So that teachers must regulate teaching and learning activities to continue even though they are through an online system, and ensure learning activities to attract more students' interest, reduce student boredom in learning, and make it easier for students to understand the material quickly. For this reason, interactive learning media is needed to make it easier for teachers and students to carry out the teaching and learning process, especially during the pandemic, besides that teachers also find it helpful in conveying material to students through interactive learning media. By using Adobe Flash software. Computer software used to create animated 2-dimensional (2D) moving images. It will be applied to the study of the classification of vertebrate animals. It is hoped that it will help teachers in biology subjects to visualize the classification of vertebrate animals in 2D objects. Teachers in carrying out their role in the learning process, need tools that can convey information to students. So that it can be used as a means to deliver learning material.
\end{abstract}

Keywords: Learning media, animation, animal classification, adobe flash, covid19. 


\section{Pendahuluan}

Perkembangan dan kemajuan teknologi saat ini sangat berperan penting dalam berbagai bidang terutama dalam bidang pendidikan, salah satunya adalah penggunaan teknologi digital berupa media pembelajaran interaktif[1]. Teknologi yang semakin maju akan mendukung sistem pendidikan demi mencapai prestasi belajar siswa yang memuaskan, karna dapat menyerap informasi secara cepat dan efisien. Teknologi juga dapat dijadikan peluang oleh guru untuk dapat mengembangkan teknik pembelajaran dan memanfaatkan media agar siswa mendapatkan hasil belajar yang maksimal.

Media pembelajaran sangat penting digunakan dalam proses belajar mengajar sehingga dapat memotivasi belajar siswa, membangkitkan semangat dan minat belajar siswa, bahkan membawa pengaruh psikologis terhadap siswa. Penggunaan media pembelajaran juga dapat meningkatkan pemahaman siswa terhadap suatu materi pembelajaran. Dalam proses penyampaian materi, pengajar (guru) dapat menggunakan media pembelajaran sebagai alat komunikasi antara siswa agar dapat mencapai tujuan pembelajaran sehingga dapat memudahkan siswa dalam memahami materi.

Seperti yang kita ketahui sekarang ini beberapa negara masih menerapkan kebijakan untuk melakukan lockdown untuk mencegah penularan virus corona (Covid 19). Di indonesia sendiri, diperlukan kebijakan pembatasan sosial bersekala besar (PSBB) Maka semua kegiatan diluar rumah salah satunya kegiatan belajar mengajar harus diberhentikan sementara waktu sampai pandemi berakhir. Dan beberapa pemerintah memutuskan untuk menerapkan kebijakan kerja dirumah, dan mulai menerapkan metode belajar daring (dalam jaringan). Guru harus mengatur kegiatan belajar mengajar tetap berjalan meskipun melalui sistem daring. Sehinga beberapa guru mengaku, jika belajar online ini tidak seefektif kegiatan belajar tatap muka. Solusinya, pengajar dituntut untuk memastikan kegiatan belajar agar lebih menarik sebagai inovasi dengan memanfaatkan belajar online, dan guru harus siap menggunakan teknologi yang sesuai dengan perkembangan zaman salah satunya dengan cara mendesain media pembelajaran agar mempermudah guru dan siswa melakukan proses belajar mengajar terutama pada masa pandemi agar lebih menarik, selain itu juga guru merasa terbantu dalam menyampaikan materi terhadap siswa melalui media pembelajaran interaktif terutama pada materi klasifikasi hewan vertebrata pada kelas VII di SMP (studi kasus di SMP Islam Plus Tahfidz Al-Qur'an Sukarema) karena materi ini sesuai dengan kurikulum untuk di jadikan bahan media intraktif dan membantu guru dan siswa terutama di masa pandemi ini, agar lebih efektif dan efisien. 
Infotek : Jurnal Informatika dan Teknologi

Vol. 5 No. 1, Januari 2022

Hal. $x x-x x$

e-ISSN 2614-8773

DOI : 10.29408/jit.v5i1.4388 Link : https://dx.doi.org/10.29408/ jit.v5i1.4388

Berdasarkan permasalahan latar belakang diatas

maka diperlukan media pembelajaran interaktif berbasis multimedia untuk dapat meningkatkan pemahaman dan minat belajar siswa kelas VII di SMP Islam Plus Tahfidz Al-Qur'an Sukarema pada pelajaran biologi khususnya materi klasifikasi hewan vertebrata.

Untuk mengatasi permasalahan tersebut, penulis berinisiatif untuk membuat sebuah media pembelajaran yang berjudul "Media Pembelajaran Interaktif Berbasis Flash Pada Materi Klasifikasi Hewan Vertebrata Mata Pelajaran Biologi Kelas VII Di SMP Islam Plus Tahfidz Al-Qur'an Sukarema" Media pembelajaran ini dibuat untuk meningkatkan minat belajar siswa, menambah semangat dan motivasi siswa selama belajar hingga didapatkan tujuan pembelajaran yang maksimal, mengurangi kejenuhan siswa dalam belajar, serta memudahkan siswa memahami materi dengan cepat.

\section{Tinjauan Pustaka}

\subsection{Penelitian Terkait}

Beberapa penelitian terkait untuk menggunakan media pembelajaran interaktif dalam meningkatkan minat belajar peserta didik, berikut beberapa peneliti :

- Penelitian oleh Aris Sudianto dan Lalu Muhammad Samsu. Yang berjudul "Penerapan Media Pembelajaran Interaktif Pelajaran Bahasa Indonesia Berbasis Android
Untuk Kelas VII Madrasah Tsanawiyah Nahdlatul Wathan Ketangga Sebagai Upaya Untuk Peningkatkan Minat Belajar Siswa". Bahwasanya media pembelajaran interaktif lebih efektif dari metode pembelajaran ceramah. Karena metode ceramah hanya membuat siswa lebih menjadi pasif dan apabila menerapkan media pembelajaran interaktif lebih memancing respon siswa terhadap suatu pelajaran[3].

- Peneiliatan oleh Hariman Bahtiar. Dengan jurnal yang berjudul "Sistem Informasi Wisata dan Budaya Pulau Lombok dengan Multimedia Interaktif Untuk Meningkatkan Kunjungan Wisata". Maka dapat disimpulkan bahwa sistem informasi dengan menggunakan teknologi multimedia lebih efektif karena :

Sistem informasi berbasis multimedia dapat meningkatkan kinerja serta meningkatkan efektifitas informasi[4]

- Penelitian oleh Fathurrahman, Yupi Kuspandi Putra, dan Muhamad Sadali. Dengan jurnal yang berjudul "Media Pembelajaran Interaktif Pengenalan Huruf Berbasis Flash Pada Siswa Pendidikan Anak Usia Dini (PAUD) (Studi Kasus : Kelompok Belajar Tarbiyatul Ummah Tanak Kaken Sakra Barat)" Pembuatan media pembelajaran interaktif berbasis adobe flash cs6 pada media pembelajaran mengenal huruf-huruf abjad untuk Pendidikan Anak Usia Dini (PAUD) ditunjukkan agar dapat 
Infotek : Jurnal Informatika dan Teknologi

Vol. 5 No. 1, Januari 2022

Hal. $x x-x x$

e-ISSN 2614-8773

DOI : 10.29408/jit.v5i1.4388 Link : https://dx.doi.org/10.29408/ jit.v5i1.4388

mempermudah guru dan siswa dalam proses belajar mengajar[5]

- Penelitian yang dilakukan oleh Fithry Tahel dan Erwin Ginting. Yang berjudul "Penerapan Aplikasi Flash Dalam Media Pembelajaran Mewarnai Gambar Untuk Meningkatkan motoric halus". Penerapan Aplikasi Flash yang mengedepankan keleluasaan serta responsif dapat merubah proses pembelajaran manual menjadi pembelajaran yang efektif dan efisien secara terkomputerisasi[6].

- Penelitian oleh Kadek Aditya Pradipta Yasa, Ketut Udy Ariawan, dan Wayan Sutaya. Dengan jurnal yang berjudul "Pengembangan Media Pembelajaran Interaktif Berbasis Adobe Flash Pada Mata Pelajaran Prakarya Dan Kewirausahaan Materi Elektro Listrik Untuk Kelas XI Mipa Dan Ips Di SMA Negeri 3 Singaraja" Penelitian ini bertujuan mengembangkan media interaktif berbasis adobe flash pada mata pelajaran prakarya dan kewirausahaan materi elektro listrik[7]

Penelitian yang dilakukan oleh Mar'atush Sholichah Muntaha Rahmi, M. Arif Budiman, dan Ari Widya Ningrum. Dengan jurnal yang berjudul "Pengembangan Media Pembelajaran Interaktif Macromedia Flash 8 pada Pembelajaran Tematik Tema Pengalamanku" bahwa media interaktif berbasis macromedia flash 8 valid dan praktis digunakan pada tema pengalamanku kelas ॥ Sekolah Dasar[8].

\subsection{Landasan Teori}

1. Multimedia

Multimedia adalah penggunaan komputer yang digunanakan untuk menyajikan dan mengkombinasikan suara, gambar, teks, video, animasi, dan audio dengan alat bantu (tool) dan tautan (link) sehingga pengguna dapat melakukan navigasi, berinteraksi, berkarya, dan berkomunikasi. Dalam definisi lain, multimedia merupakan salah satu media komunikasi dan menemukan informasi pada komputer yang menggabungkan antara teks, audio, animasi, dan video. Gabungan dari berbagai elemen tersebut dapat disimpan, dikirim, ditampilkan, maupun diproses dengan perangkat tertentu[9]

Pengertian lainnya menjelaskan bahwa secara etimologis multimedia berasal dari bahasa latin "multi dan medium". Dimana kata multi yang berarti bermacam-macam atau banyak, dan medium yang berarti sesuatu yang dipakai untuk menyampaikan atau membawa sesuatu. Media merupakan kata yang berasal dari bahasa latin medius (bentuk jamak dari medium) yang secara harfiah berarti tengah, perantara, atau pengantar. Media juga di artikan sebagai alat untuk mendistribusikan dan peroses menyalurkan informasi[10]. 


\section{Elemen Multimedia}

Menurut Herman Dwi Surjono (2017). Elemen multimedia diglongkan menjadi dua, yaitu elemen multimedia berbasis waktu (kontinyu) contohnya animasi, suara dan video. Sedangkan elemen multimedia yang tidak berbasis waktu (diskret) contohnya teks dan gambar. Jenis multimedia ini memiliki peran yang penting dalam penyajian informasi, karena masing-masing memiliki tujuan tertentu tergantung kegunaanya dan memliki kekurangan dan kelebihan sendiri[11].

\section{Pengertian Flowmap}

Flowmap adalah campuran peta dan flow chart yang menunjukkan pergerakan benda dari satu lokasi ke lokasi lain. Seperti jumlah orang migrasi, jumlah barang yang diperdagangkan atau jumlah paket dalam jaringan. Flowmap menolong analis dan programmer untuk memecahkan masalah ke dalam segmen atau bagian yang lebih kecil dan menolong dalam menganalisis alternatif-alternatif dalam pengoperasian[12].

\section{Media Pembelajaran}

Media didefinisikan sebagai cara mengomunikasikan informasi atau ide. Media disebut juga sebagai pembawa informasi/pesan dari sumber informasi ke penerima, dan bila pesan itu ditujukan untuk mengubah perilaku penerima, maka media tersebut disebut media pembelajaran[13].

Media Pembelajaran menggunakan teknologi yaitu dengan software bebarin yang di pilih karna di dalamnya memadukan beberapa media yang di pilih dalam pembelajaran seperti kombinasi antara lain text, gambar, video, voice yang dapat memaduhkan media yang dikemas satu aplikasi atau software sehingga dapat memungkinkan pengunaanya dapat melakukan navigasi, intraksi, berkriasi dan berkomunikasi[14]

Media pembelajaran adalah media yang sangat penting dalam bidang pendidikan, yang berfungsi sebagai alat bantu dalam peroses pembelajaran dengan tujuan menyampaikan pesan atau informasi. Media pembelajaran juga dapat digunakan untuk merangsang pikiran, perhatian, kemampuan dan perasaan siswa sehingga dapat mendorong semangat peroses belajar peserta didik. Secara umum media pembelajaran memiliki peran yang penting, mulai dari meningkatkan motivasi belajar siswa/pelajar sehingga mampu meningkatkan prestasi belajar, memperjelas materi pembelajaran, serta mengatasi keterbatasan waktu yang di gunakan pengajar dalam penyampaian materi dan mampu meningkatkan daya ingat peserta didik.

Secara umum media pembelajaran terdapat beberapa kelompok yaitu:

1. Media audio, yaitu media pembelajaran dengan hanya memanfaatkan indra pendengaran peserta didik dalam penyampain pesan pembelajaran. Pesan atau informasi yang di terima berupa suara, bunyi tiruan dan music. 
Infotek : Jurnal Informatika dan Teknologi

Vol. 5 No. 1, Januari 2022

Hal. $x x-x x$

e-ISSN 2614-8773

DOI : 10.29408/jit.v5i1.4388 Link : https://dx.doi.org/10.29408/ jit.v5i1.4388

2. Media visual, yaitu jenis media pembelajaran yang hanya melibatkan indra pengelihatan pelajar, tergantung dari pengelihatan pelajar contohnya seperti buku, jurnal, poster, dan media cetak lainnya.

3. Media audio- visual, yaitu jenis yang di gunakan dalam media pembelajaran dengan memanfaatkan indra pendengaran dan indra pengelihatan dalam suatu peroses atau kegiatan. Dalam menerima pesan atau informasi sebagai contoh seperti video, filem, dan program TV[15]

5. Media pembelajaran interaktif

Media pembelajaran interaktif adalah sistem penyampain sebuah pembelajaran yang menyajikan materi menggunakan video rekaman dari perangkat computer kepada peserta didik yang tidak hanya melihat dan mendengar video dan suara saja, akan tetapi memberikan respon yang aktif. Disebut multimedia interaktif karena media tersebut memiliki unsur audio- visual dan termasuk animasi[16]

6. Materi klasifikasi Hewn vertebrata

Vertebrata merupakan hewan yang memiliki tulang belakang atau punggung. Tulang belakang adalah tulang yang beruas-ruas dan berderet dari leher sepanjang punggung sampai ekor. Sumsum tulang belakang yang terdapat dalam ruas-ruas tulang belakang dan otak merupakan susunan saraf pusat[17].

Hewan vertebrata dibagi menjadi 5 kelompok:
1. Aves

Aves (burung) merupakan hewan vertebrata yang punya sayap, paruh, dan tubuhnya dipenuhi bulu. Aves tergolong ke dalam kelompok hewan yang memiliki suhu tubuh tetap. Burung dapat bernafas dengan paruparu yang dibantu oleh pundi-pundi udara saat terbang. Contoh hewan yang termasuk aves adalah merpati, burung hantu, burung unta dan lain-lain.

2. Mamalia

Merupakan hewan vertebrata yang memiliki kelenjar susu. Mamalia mempunyai tubuh yang ditutupi oleh rambut, mampu mempertahankan suhu tubuhnya meskipun lingkungan terlalu panas atau dingin.

3. Reptil

Reptil termasuk kedalam kelompok hewan vertebrata yang bernapas dengan paru-paru, hewan ini punya sisik yang kering ditubuhnya dan cangkang telur yang kasar, sampai saat ini ada 8.300 spesies reptile didarat maupun di air.

4. Amphibi

Merupakan hewan yang hidup di dua alam yaitu darat dan air. Hewan ini punya tubuh yang lembab, kulit berpori dan telur yang lembut.

\section{Pisces}

Merupakan jenis hewan vertebrata yang bersifat berdarah dingin yang hidup didalam air 
tawar, air laut, maupun air payau. Ciri ikan antara lain bernapas dengan insang dan punya sisik yang basah.

\section{Metode Penelitian}

\subsection{Metode Pengumpulan Data}

1. Observasi

Observasi merupakan Teknik pengumpulan data melalui pengamatan dan pencatatan tehadap suatu peristiwa yang berhubungan dengan object penelitiannya. Pengamatan dilakukan di SMP Islam Plus Tahfidz Al-Qur'an Sukarema.

\section{Wawancara}

Wawancara merupakan Teknik yang dilakukan oleh peneliti secara langsung dilokasi untuk mendapatkan informasi yang akurat, melalui tatap muka dan tanya jawab dengan para guru.

3. Studi Pustaka

Metode yang dilakukan dengan membaca dan mempelajari literatur serta mengumpulkan informasi, dokumen-dokumen atau buku sebagai petunjuk dalam sebuah penelitian.
1. Tahap Analisis

Meliputi peroses perancangan media pembelajaran, menetapkan tujuan media pembelajaran serta menyiapkan materi yang akan di sajikan.

2. Tahap Desain Dan Peroses

System design dilakukan berdasarkan luaran atau output oriented, artinya proses dan inputnya dilihat setelah di tentukan luaran yang diinginkan, sehingga dapat dilihat dari system media pembelajaran interaktif.

3. Experimen Dan Pengujian

Hasil yang sudah dilakukan, akan diuji coba untuk melihat apakah system yang dihasilkan sesuai yang diinginkan peneliti.

4. Evaluasi Hasil Experimen Dan Pengujian Setelah dilakukan pengujian dan eksperimen yang sudah dilakukan, maka terlihat perbedaan dari hasil yang dilakukan sebelumnya, apakah dengan memanfaatkan media pembelajaran mengunakan adobe flash dapat membantu guru dalam peroses pengajaran dengan baik, serta meningkatkan hasil belajar peserta didik.

\subsection{Tahapan Penelitian}

Adapun tahapan dari penelitian ini meliputi beberapa tahapan diantaranya;

Tahap pengumpulan informasi mengenai datadata yang di butuhkan dalam membuat media pembelajaran interaktif. 


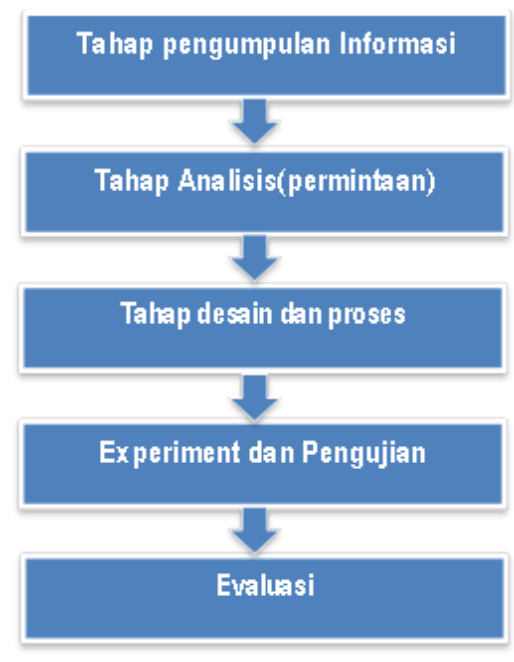

Gambar 1 Tahapan Penelitian

\subsection{Struktur Navigasi}

Berikut adalah gambar desain diagram navigasinya:

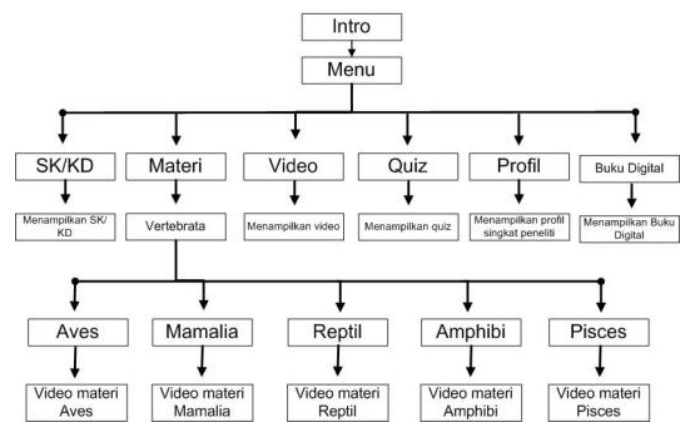

Gambar 2 Struktur navigasi

Perancangan struktur navigasi dalam pembuatan media pembelajaran interaktif ini menggunakan struktuk hirarki. Perancangan ini menjelaskan yang akan dipilih seperti di gambar. Yang dimana akan tampil intro yang mengarah ke menu dengan menekan tombl "mulai" yang sudah disediakan. Pada menu pembelajaran biologi terdapat lima menu pilihan, dimana ada menu SK/KD, Materi, video, quiz, profil dan buku digital.

\subsection{Storyboad}

Tabel 1. Storyboad

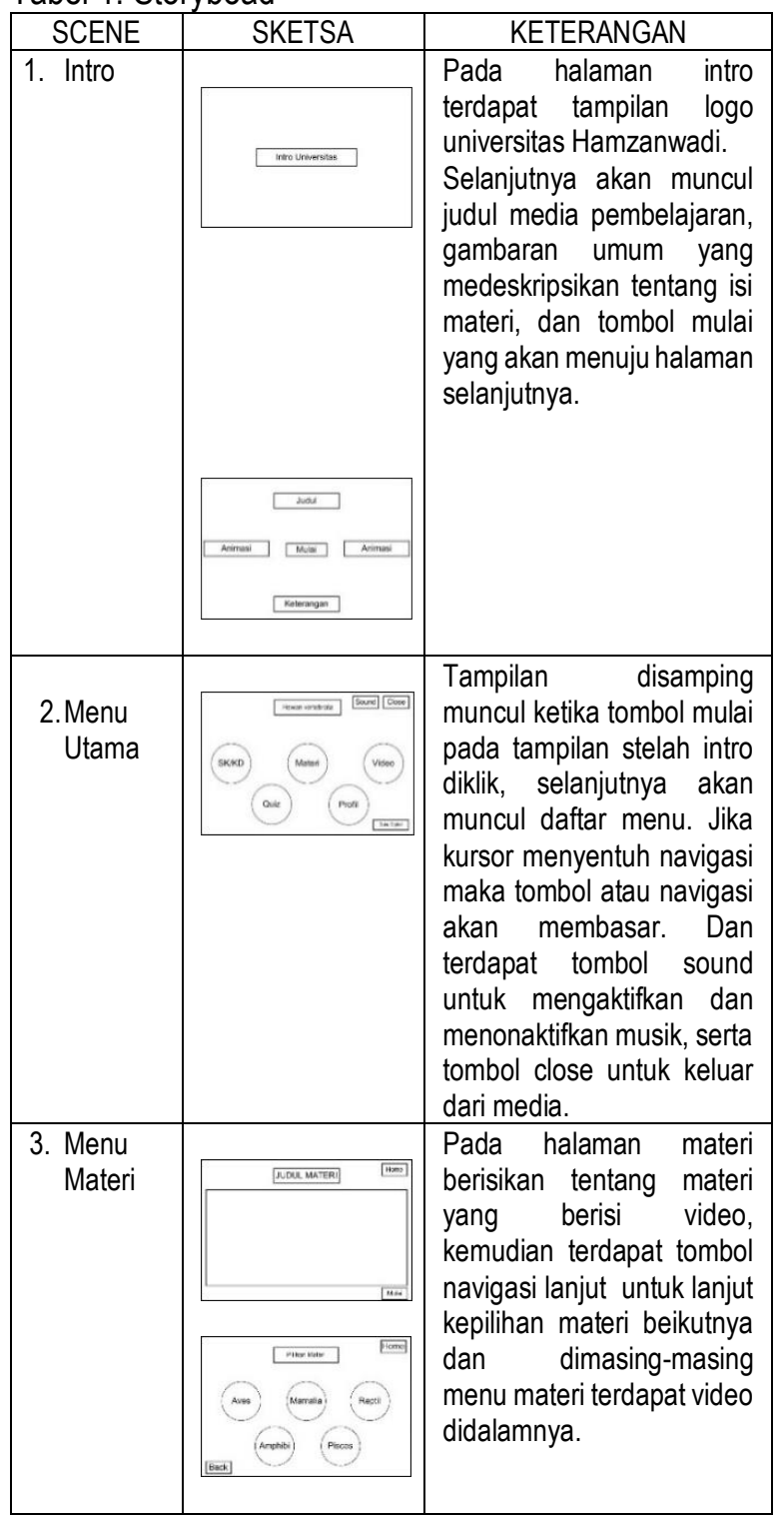




\subsection{Proses Pembuatan Media Pembelajaran}

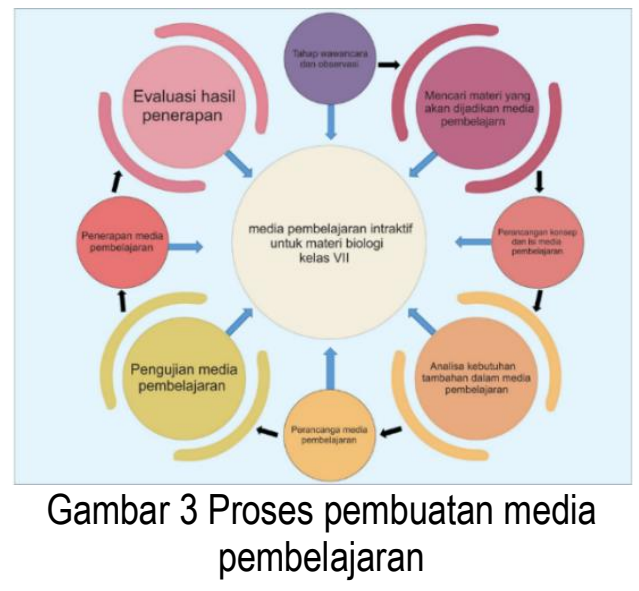

Adapun proses pembuatan media pembelajaran interaktif ini adala sebagai berikut:

1. Peneliti melakukan proses tahap wawancara dan observasi langsung dilapangan.

2. Kemudian mencari materi melalui e-book yang akan dijadikan media pembelajaran.

3. Lalu merancang konsep dan isi media pembelajaran.

4. Analisis kebutuhan tambahan dalam media pembelajaran

5. Pada tahap design dilakukan desain produk untuk perancangan media pembelajaran.

6. Hasil yang sudah dibuat akan dilakukan pengujian untuk melihat apakah system yang dihasilkan sesuai yang diinginkan peneliti.

7. Penerapan media pembelajaran dilakukan di lokasi penelitian.

8. Setelah melakukan penerapan maka akan di lakukan evaluasi hasil penerapan.

\section{Hasil dan Pembahasan}

Agar bisa menjalankan media pembelajaran interaktif ini, guru hanya perlu menggunakan PC atau laptop. Langkah-langkah untuk membukanya adalah sebagai berikut:

- Klik dua kali pada icon aplikasi Adobe Flash Media Pembelajaran Interaktif Klasifikasi Hewan Vertebrata.

- Selanjutnya akan langsung ke interface halaman intro media pembelajaran.

1. Halaman Opening

Tampilan dari halaman opening atau pembuka setelah dijalankan, seperti gambar di bawah ini:

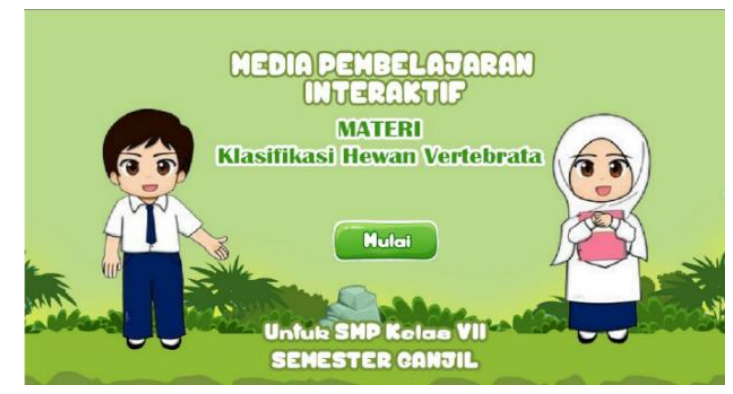

Gambar 8 Halaman opening setelah di jalankan 2. Halaman Menu

Tampilan dari halaman menu utama setelah di jalankan, seperti gambar di bawah ini: 


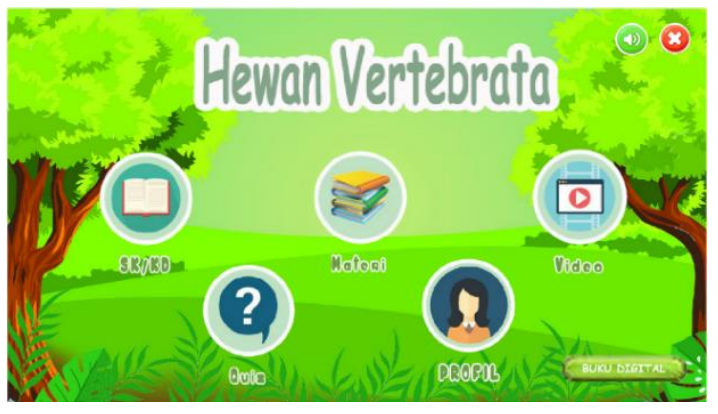

Gambar 9 Halaman menu setelah di jalankan

\section{Halaman Materi}

Tampilan dari halaman materi setelah dijalankan, seperti gambar di bawah ini:

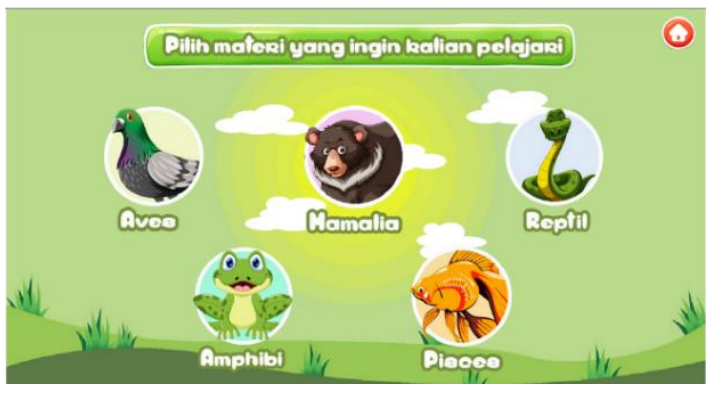

Gambar 10 Halaman pilihan materi setelah di jalankan

\section{Halaman Video}

Tampilan dari halaman video setelah dijalankan, seperti gambar di bawah ini :

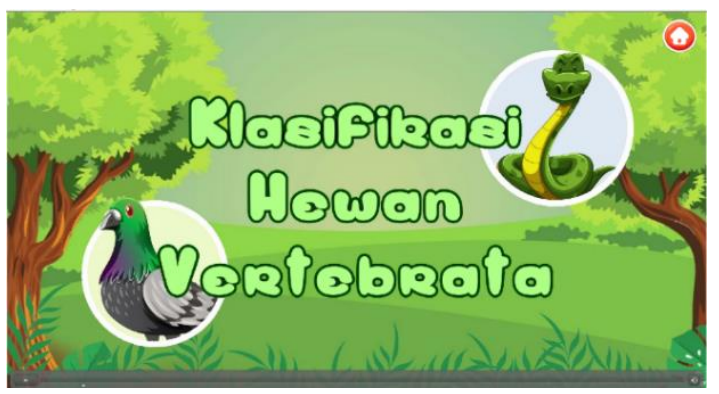

Gambar 11 Halaman video setelah di jalankan

Tabel 2. Uji coba sistem

\begin{tabular}{|c|c|c|c|}
\hline \multirow[t]{2}{*}{ NO } & \multirow[t]{2}{*}{ Bagian-Bagian Dalam Media } & \multicolumn{2}{|c|}{$\begin{array}{l}\text { Indikator } \\
\text { Pegujian }\end{array}$} \\
\hline & & Ok & NO \\
\hline
\end{tabular}

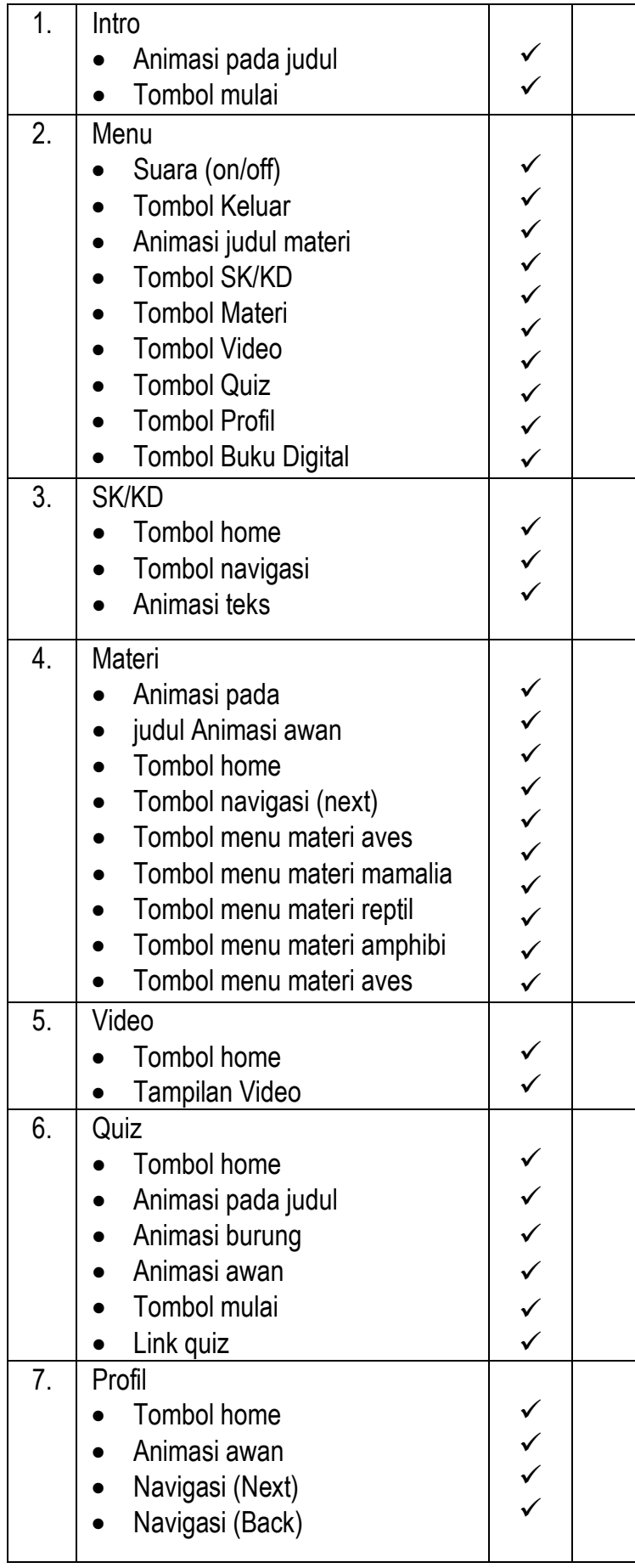

Untuk menjalankan media pembelajaran interaktif ada beberapa hal yang perlu diperhatikan oleh guru atau siswa, antara lain:

1. Media pembelajaran interaktif yang disimpan dengan format file .exe atau .swf dapat berjalan langsung, sehingga pengguna bisa 
menggunakan media tanpa harus menginstal softwaren Adobe Flash dalam PC/ laptop.

2. Jika pengguna mengakses link untuk soal-soal quiz berbentuk pilihan ganda yang terhubung langsung ke Google Form, hendaknya pengguna menggunakan file media pembelajaran dengan format.swf.

3. Di dalam media pembelajaran tersebut disertai dengan beberapa video yang dimana video tersebut akan hilang jika file media pembelajaran dipindah atau copy ke perangkat yang lain.

\section{Kesimpulan}

Kesimpulan dari penelitian ini adalah :

1. Dengan adanya media pembelajaran interaktif ini bisa membantu siswa dalam belajar daring (dalam jaringan) terutama pada masa pandemi (covid 19) seperti saat ini.

2. Pembuatan media pembelajaran telah dibuat menggunakan aplikasi Adobe Flash sesuai dengan perancangan antarmuka yang telah dirancang sebelumnya sehingga media pembelajaran sudah dapat digunakan dalam proses belajar mengajar agar lebih efektif digunakan.

3. Dengan adanya media pembelajaran ini akan dapat membantu mengevesiensi waktu dan tenaga baik itu guru maupun siswa.

4. Media pembelajaran interaktif ini dibuat dengan memasukkan kelima elemen yaitu gambar, video, suara, teks dan animasi. Sehingga meningkatka ketertarikan dan semangat siswa dalam belajar.

\section{Daftar Pustaka}

[1] Hariman Bahtiar;Muhammad Djamaludin; M Rizal Supriandi, "Pengenalan Arsitektur Rumah Tradisional Desa Belek Sembalun Lawang Lombok Dengan Menggunakan Animasi 3d Menggunakan Blender Sebagai Media Pembelajaran," Infotek J. Inform. dan Teknol., vol. 3, no. 1, 2020.

[2] M. Bahtiar, "Visualization Of The Traditional House Architecture Of Belek Sembalun Lawang Village By Using 3D Animation Visualization Of The Traditional House Architecture Of Belek Sembalun Lawang Village By Using 3D Animation," Conf. Ser., vol. 1539, 2020, doi: 10.1088/17426596/1539/1/012021.

[3] L. M. S. Aris Sudianto, "Penerapan Media Pembelajaran Interaktif Pelajaran Bahasa Indonesia Berbasis Android Untuk Kelas Vii Madrasah Tsanawiyah Nahdlatul Wathan Ketangga Sebagai Upaya Untuk Peningkatkan Minat Belajar Siswa Aris," Ayan, vol. 8, no. 5, p. 55, 2019.

[4] Hariman Bahtiar, "Sistem Informasi Wisata dan Budaya Pulau Lombok dengan Multimedia Intraktif Untuk Meningkatkan Kunjungan Wisata," Infotek J. Inform. dan Teknol., vol. 1, no. 1, pp. 1-10, 2018.

[5] dan M. S. Fathurrahman, Yupi Kuspandi Putra, "Media Pembelajaran Interaktif Pengenalan Huruf Berbasis Flash Pada Siswa Pendidikan Anak Usia Dini (PAUD) (Studi Kasus : Kelompok Belajar Tarbiyatul Ummah Tanak Kaken Sakra Barat)," Infotek J. Inform. dan Teknol., vol. 3, no. 2, pp. 211-219, 2020.

[6] F. Tahel and E. Ginting, "Penerapan Aplikasi Flash Dalam Media Pembelajaran Mewarnai Gambar Untuk Meningkatkan Motorik Halus," J. Inform. Kaputama(JIK), 
vol. 2, no. 1, pp. 34-43, 2018.

[7] I. W. S. Kadek Aditya Pradipta Yasa1, Ketut Udy Ariawan2, "Pengembangan Media Pembelajaran Interaktif Berbasis Adobe Flash Pada Mata Pelajaran Prakarya Dan Kewirausahaan Materi Elektro Listrik Untuk Kelas Xi Mipa Dan Ips Di Sma Negeri 3 Singaraja," J. Pendidik. Teknol. dan Kejuru. Vol., vol. 14, no. 2, pp. 199-209, 2017.

[8] A. W. Mar'atush Sholichah Muntaha Rahmi1, M. Arif Budiman, "Pengembangan Media Pembelajaran Interaktif Macromedia Flash 8 pada Pembelajaran Tematik Tema Pengalamanku," Int. J. Elem. Educ., vol. 3, no. 2, pp. 178-185, 2019.

[9] Y. Irawan, "Media Pembelajaran Bahasa Inggris Dasar Menggunakan Macromedia Flash 8 Di Tk Kartika 1.50 Kecamatan Sail Kota Pekan Baru," J. Inform. Manaj. dan Komput., vol. 11, no. 2, 2019, doi: 10.36723/juri.v11i2.170.

[10] A. U. Siahaan, "Media Pembelajaran Bahasa Inggris Untuk Pengenalan Anggota Tubuh Berbasis Multimedia Interaktif," Rxuqdo Ri 'Ljlwdo (Gxfdwirq? \&Rppxqlfdw/rq? Dqg \$Uwv, vol. 1, no. 1, 2018.

[11] P. D. Prof. Herman Dwi Surjono, M.Sc., M.T., Multimedia Pembelajaran Interaktif Konsep dan Pengembangan, vol. 44, no. 8. 2011.

[12] B. E. P. M Haidar Bagir, "Analisis Perancangan Sistem Informasi
Pergudangan di CV . Karya Nugraha," J. Media Tek. Sist. Ind., vol. 2, no. 1, pp. 20 29, 2018.

[13] L. I. Wati, "Pengembangan Media Pembelajaran Interaktif Berbantuan Adobe Flash Cs6 Pada Mata Pelajaran Teknologi Perkantoran di Kelas X OTKP SMK Negeri 1 Lamongan," J. Pendidik. Adm. Perkantoran (JPAP, vol. 9, no. 1, pp. 6576, 2021.

[14] K. Fajarisman, Asri Widiatsih, "PENGEMBANGAN Media Pembelajaran Berbasis Adobe Flash Cs6 Pada Mata Pelajaran Bahasa Mandarin Untuk SMP/MTs," vol. 5, no. 1, pp. 1-16, 2020.

[15] L. Riyan Maulana, Risma Zaizafun Ismi, "Rancangan Animasi Media Pembelajaran Bahasa Inggris Ke Indonesia Untuk Anak Usia Dini Berbasis Adobe Flash," J. Sains Komput. dan Inform., vol. 4, no. September, pp. 379-385, 2020.

[16] Nur Lailiyah, "Pengembangan Media Pembelajaran Interaktif Berbasis Flash Untuk Pembelajaran Keterampilan Menuliskan Kembali Cerita Siswa Kelas IV SD," JPGSD, vol. 06, no. 07, pp. 11501159, 2018.

[17] Nila Zuqistya, VERTEBRATA fakultas ilmu tarbiah dan keguruan universitas islam negeri syarif hidayutullah jakarta. jakarta: fakultas ilmu tarbiah dan keguruan universitas islam negeri syarif hidayutullah jakarta, 2014. 